\title{
The Hungarian Constitutional Court's Decision on the Protection of Groundwater
}

\author{
Decision No. 13/2018. (IX. 4.) AB of the Constitutional Court of \\ Hungary
}

Gábor Kecskés*

\begin{abstract}
On 28 August 2018, the Constitutional Court of Hungary delivered a milestone decision [Decision No. 13/2018. (IX. 4.) AB] in relation to the protection of groundwater with reference to the general protection of the environment as a constitutionally protected value. The President of the Republic pointed out in his petition to the Constitutional Court that two sections of the draft legislation are contrary to the Fundamental Law by violating Articles B(1), P(1) and XXI(1) of the Fundamental Law by permitting water abstraction with much lower standards. Adopted by the majority along with concurring and dissenting opinions, the decision is an important judicial achievement in the general framework of constitutional water and environmental protection. It also confirms the nonderogation principle elaborated by the Constitutional Court. The Constitutional Court had the opportunity and an 'open mind' to take into consideration numerous sources of scientific professional evidence on the stock of water and groundwater abstraction. The decision was acclaimed for its environmental orientation, and even more, for developing the 25-year old standards of constitutional review in environmental matters by elaborating on the implicit substance of several articles enshrined in the new Fundamental Law (e.g. Articles P and XXI).
\end{abstract}

Keywords: environmental impact assessment, precautionary principle, nonderogation principle, Constitutional Court of Hungary, groundwater.

\section{Historical Background and the Petition}

The Hungarian Parliament passed new legislation aiming to amend the Act LVII of 1995 on Water Management ${ }^{1}$ (Water Management Act). The Act was not

* Gábor Kecské: research fellow, Eötvös Loránd Research Network, Centre for Social Sciences, Institute for Legal Studies, Budapest; associate professor of law, Széchenyi István University, Győr.

1 The amending legislation is available (in Hungarian) at www.parlament.hu/ irom41/00384/00384-0007.pdf. 
promulgated, since the President of the Republic raised concerns regarding its constitutionality ${ }^{2}$ based on Articles 6(4) and 9(3)(i) of the Fundamental Law. ${ }^{3}$

The main objective of the newly adopted, but not yet promulgated legislation ${ }^{4}$ had been unfolded in the justification part of the draft act proposed by the Hungarian Minister of Interior and submitted to the National Assembly. ${ }^{5}$ The proclaimed aim was to ease and revoke the existing restrictions applicable to the groundwater wells (such as obtaining permission for abstracting groundwater) to impose fewer restrictions on the use of the water base for watering and irrigation. ${ }^{6}$ The draft act focused on household purposes rather than agricultural and water utility issues. The two controversial sections were Section $1^{7}$ and Section $4^{8}$ of the draft act. Section 1 would allow water abstraction activities without permission and notification until the depth of 80 meters, while Section 4 added the scope of unauthorized activities and additional procedures and details which were to be regulated by the government in a future government decree.

2 The petition is available (in Hungarian) at www.keh.hu/pic/upload/files/ 20180730_ab_inditvany_t384_vizkivetelek.pdf.

3 According to Article 6(4) if the President of the Republic considers the Act or any of its provisions to be in conflict with the Fundamental Law and no examination under paragraph (2) has been conducted, he or she shall send the Act to the Constitutional Court for examination of its conformity with the Fundamental Law. According to Article 9(3) of the Fundamental Law, the President of the Republic "may send adopted Acts to the Constitutional Court for an examination of their conformity with the Fundamental Law or may return them to the National Assembly for reconsideration."

4 According to Article 24(2), the Constitutional Court shall examine adopted Acts not yet promulgated for conformity with the Fundamental Law.

5 On the water abstraction and its EU legal aspects, see e.g. János Ede Szilágyi et al., 'A felszín alatti vízkivételek liberalizálása az Alaptörvény és az európai uniós jog tükrében’, Hidrológiai Közlöny, 2017/4, pp. 14-23.

6 On the general analysis of water within the context of constitutions, see e.g. Marcel Szabó, 'The New Concept of the Constitutional Protection of Water Bases', in Marcel Szabó \& Veronika Greksza (eds.), Right to Water and the Protection of Fundamental Rights in Hungary, Pécs, 2013, pp. 2-15. On water law in the context of Fundamental Law, see e.g. László Fodor \& Ágnes Bujdos, 'Right to Environment and Right to Water in the Hungarian Fundamental Law', in Szabó \& Greksza (eds.) 2013, pp. 34-48.

7 The text of Section 1 of the amending legislation: "Section 1 Section 28/A (1) of the Act LVII of 1995 on Water Management (hereinafter: Water Management Act) shall be replaced by the following provision: "(1) With the exception of the activities that can be carried out without permission on the basis of the law and of the activities subject to reporting, water rights permission shall be required for a) performing water works, constructing or transforming a water project (water rights implementation permit), b) putting into service and for the operation of water projects, for water usage (water rights operation permit), and c) termination of a water project (termination permit).«"

8 The text of Section 4 of the amending legislation: "Section 4 Section 45(7)(s) of Water Management Act shall be replaced by the following provision: (The Government shall be authorized to specify in a decree) "s) the scope of activities that may be commenced and carried out without water rights permit and notification, the elements of content of posterior notification in these cases, and the rules of posterior control by the authority, as well as the scope of activities that can be commenced and carried out after notifying it to the water management authority and the elements of content of ex post notification in these cases, and the rules of posterior control by the authority. «" 
The President of the Republic pointed out that the amending legislation's previously mentioned two sections was contrary to the Fundamental Law for violating Articles $\mathrm{B}(1)$ (rule of law), $\mathrm{P}(1)$ (protection of common heritage of the nation) and XXI(1) (right to a healthy environment) of the Fundamental Law. The President of the Republic recalled the aim of the amending legislation, such as

"the elaboration of a regulation that does not require any permission or reporting procedure to be carried out, provided that the depth of the well is not more than 80 meters. Accordingly, a water project development shallower than 80 meters to secure water abstraction not exceeding household water demand may be established without it having to be notified or permitted."9

This alleviation and derogation could easily cause considerable deterioration ${ }^{10}$ in groundwater quality and quantity, however, the current legislation requires permission and notification for such activities which should take into account the quality and quantity issues. The President of the Republic also underlined in the petition that maintaining the obligation for obtaining the permission for water abstraction is necessary, especially

"in the case of (i) interventions into cold and thermal karst stocks of water (water bodies) irrespectively to the depth of the intervention and the quantity of water, and (ii) water abstractions for economic purpose, irrespectively of the depth and the water quantity." 11

Furthermore, the President of the Republic recalled the opinion of the Deputy Commissioner for Future Generations (Deputy Commissioner) ${ }^{12}$ of May 2017. The Deputy Commissioner cited Article P of the Fundamental Law which requires the specific protection of the common heritage of national resources such as water, ${ }^{13}$ while the amended legislation would allow the unimpeded abstraction of water without having to acquire a permit until the depth of 80 meters.

Moreover, the specific constitutional objectives were also missing from the reasoning of the draft act. The President considered the alleviation to be contrary

9 Decision No. 13/2018. (IX. 4.) AB, Reasoning [2].

10 On the general protection of groundwater in the global sphere, see Stefano Burchi \& Kerstin Mechlem (eds.), 'Groundwater in International Law. Compilation of Treaties and Other Legal Instruments', UNESCO-FAO, Rome, 2005. On the general protection of groundwater in the EU, see Directive 2006/118/EC of the European Parliament and of the Council of 12 December 2006 on the protection of groundwater against pollution and deterioration.

11 Id. Reasoning [2].

12 The Deputy Commissioner delivered a statement on the protection of groundwater reserves, see in Hungarian at www.ajbh.hu/documents/10180/2762244/Elvi+\%C3\%A1ll\%C3\%A1sfoglal \%C3\%A1s+a+felsz\%C3\%ADn+alatti+vizek+v\%C3\%A9delm\%C3\%A9ben.pdf/ff6d9fac-8b2eb8e6-a05f-923cac46bfc7.

13 See e.g. Anikó Raisz, 'Water as the Nation's Common Heritage in the Frame of the Common Heritage of Mankind', in Szabó \& Greksza (eds.) 2013, pp. 84-96. 
to the non-derogation principle ${ }^{14}$ which is the leading principle for the quality of environmental and quantity of environmental elements within the practice of the Constitutional Court of Hungary. ${ }^{15}$ The President of the Republic cited the concerns raised within the joint declaration authored by the representatives of eleven professional organizations regarding the new act. ${ }^{16}$

Thus, according to the President of the Republic, the amending legislation does not fulfill the requirements concerning state obligations arising from Article $\mathrm{P}(1)$ of the Fundamental Law, since it lacks proper justification based on an environmental impact assessment, and clearly violates the non-derogation and the precautionary principle. The petition emphasizes that for the time being, the limit for abstracting groundwater is 50 meters in Hungary, and water abstraction for agricultural purposes can be permitted up to 50 meters under controlled circumstances. ${ }^{17}$ The President of the Republic recalled that the amending legislation would give almost unrestricted power to a future government decree for allowing water abstraction activities without effective prior permission and notification. In his view, this step is without guarantees and constitutional checks and is therefore contrary to Articles $\mathrm{P}(1)$ and XXI(1) of the Fundamental Law.

While it was omitted from the petition, and also from the ensuing Constitutional Court decision, it should be noted, that Hungary is contracting party to the 1991 Espoo Convention on Environmental Impact Assessment in a Transboundary Context [cf. 148/1999. (X. 13.) Government Decree, in Hungarian] and is bound by the EU directives on environmental impact

14 See the first (and since then) leading case of the Hungarian Constitutional Court of 1994, see Decision No. 28/1994. (V. 20.) AB, ABH 1994, 133, 140. On the non-derogation principle, see e.g. Gyula Bándi, 'Környezeti értékek, valamint a visszalépés tilalmának értelmezése', Iustum Aequum Salutare, 2017/2, pp. 159-181.

15 On the general issue of constitutional protection of the environment, see e.g. Lóránt Csink \& Júlia T. Kovács, 'Paradigm Shift in the Constitutional Character of Environment?', in Szabó \& Greksza (eds.) 2013, pp. 16-33.

16 See (in Hungarian) at www.keh.hu/pic/upload/files/20180730_ab_inditvany_t384_vizki vetelek.pdf, p. 4.

17 According to the experts of the HAS, the vulnerability and accessibility of groundwater is of key importance, since "Hungary - due to its location and unique geology - is exceptionally rich in groundwater. The average depth of shallow groundwater is 2-5 $\mathrm{m}$ (extremes 0-16 $\mathrm{m}$ ) depending on the precipitation. Shallow groundwater is vulnerable to surface contamination and usually not suitable for consumption. Bank filtration, on the other hand, is one of the main sources of drinking water (among others, Budapest relies solely on bank filtration). Deep groundwater is less vulnerable to contamination, but its recharge is much slower. The number of deep groundwater wells is close to 70000 nationally. Overall, approximately 95 percent of drinking water in Hungary is from groundwater source (including bank filtration). However, almost 2/3 of the sources is vulnerable." See Water in Hungary. Status Overview for the National Water Programme of the Hungarian Academy of Sciences, 2017, Budapest, p. 7-8, at https://mta.hu/data/ dokumentumok/Viztudomanyi\%20Program/Water_in_Hungary_2017_07_20.pdf. On the access to drinking water, see e.g. Erzsébet Kardos-Kaponyi, 'Access to Safe Drinking-Water in Hungary - With Particular Reference to the Issue of Arsenic in Water', in Szabó \& Greksza (eds.) 2013, pp. 49-67; János Ede Szilágyi, 'Affordability of Drinking-Water and the New Hungarian Regulation Concerning Water Utility Supplies’, in Szabó \& Greksza (eds.) 2013, pp. 68-83. 
assessment as well, ${ }^{18}$ which also foresee obligations that Hungary cannot neglect in the framework of water extraction regulation.

\section{Majority Decision}

The Constitutional Court held in Decision No. 13/2018. (IX. 4.) AB delivered on 28 August $2018^{19}$ that Section $1^{20}$ of the amending legislation on the Act LVII of 1995 on Water Management is contrary to the Fundamental Law, since the proposed legislation violates Articles $\mathrm{P}(1)$ and XXI(1) of the Fundamental Law. ${ }^{21}$

The Constitutional Court requested expert advice from the Hungarian Academy of Sciences (HAS) and the Deputy Commissioner Responsible for the Protection of the Interests of Future Generations. In its opinion the HAS pointed out that the legislation posed

"a serious threat to the domestic stocks of groundwater. A significant decrease of groundwater level is expected at several points, endangering ecosystems that depend on groundwater, including natural and agricultural plant cultures."22

The HAS also predicted the possibility of encountering serious problems related to water quality as well:

"The construction of wells without any obligation of obtaining permission or notifying the authorities of their establishment, as well as the operation of

18 See Council Directive 85/337/EEC of 27 June 1985 on the assessment of the effects of certain public and private projects on the environment; Directive 2011/92/EU of the European Parliament and of the Council of 13 December 2011 on the assessment of the effects of certain public and private projects on the environment, and Directive 2014/52/EU of the European Parliament and of the Council of 16 April 2014 amending Directive 2011/92/EU on the assessment of the effects of certain public and private projects on the environment. On specific European water issues, see e.g. Veronika Greksza, 'The Right to Water - A Specific Environmental Issue in Need of a Comprehensive European System of Guarantees', in Szabó \& Greksza (eds.) 2013, pp. 194-211.

19 The decision is available in English at https://hunconcourt.hu/uploads/sites/ 3/2019/12/13_2018_eng_final.pdf.

20 The Constitutional Court did not examine the conformity of Section 4 with the Fundamental Law, since it found that Section 1 is unconstitutional, therefore, any further review and examination on the petition's references was unnecessary. See Reasoning [73].

21 For Hungarian-language commentary, see János Ede Szilágyi, 'Az elővigyázatosság elve és a magyar alkotmánybírósági gyakorlat - Szellem a palackból, avagy alkotmánybírósági magas labda az alkotmányrevízióhoz', Miskolci Jogi Szemle, Vol. 13, Issue 2, 2018, pp. 76-91; Balázs Hohmann \& Attila Pánovics, 'Vízvédelem és elővigyázatosság - megjegyzések a 13/2018. (IX. 4.) AB határozathoz', JURA, 2019/1, pp. 305-309; Marcel Szabó, 'The Precautionary Principle in the Fundamental Law of Hungary - Judicial Activism or an Inherent Fundamental Principle? An Evaluation of Constitutional Court Decision No. 13/2018. (IX. 4.) AB on the Protection of Groundwater', Hungarian Yearbook of International Law and European Law, Vol. 7 (2019), pp. 67-83.

22 Decision No. 13/2018. (IX. 4.) AB, Reasoning [48]. 
wells without supervision would pose a great risk of contaminating our aquifers presently considered to be clean and protected, or of creating unintentional links between contaminated and non-contaminated aquifers, which would continue to deteriorate the situation in many areas of Hungary."23

This was echoed by the opinion submitted by the Deputy Commissioner ${ }^{24}$ upon the Constitutional Court's request. The Deputy Commissioner pointed out that

"removing certain activities from the scope of preliminary control by the State would make the safeguarding and the supervision of protecting natural resources dependent on voluntary law-abidance only." 25

He added that

"The Act restricts the right to a healthy environment as a fundamental right [...] the restriction is necessarily contrary to the Fundamental Law."26

The Constitutional Court pointed out that groundwater resources are finite (both in quantitative and in qualitative respect). Since these resources have only a limited capacity for renewal, an unrestricted water resource and abstraction management could endanger the sustainability of water resources. At the same time, the groundwater reserve is the exclusive property of the State in accordance with Section 4(1)(d) of the Act CXCVI of 2011 on National Assets. This means that while Article XIII(1) of the Fundamental Law (right to property) establishes the principle of social responsibility associated with property in general, this social responsibility is also specified in respect of national assets in particular, under Article 38 and the provision on the common heritage of the nation under Article $\mathrm{P}(1)$ of the Fundamental Law. The Constitutional Court emphasized that the concepts of national asset and the common heritage of the nation are not identical terms. While "property shall entail social responsibility", this responsibility must be reconciled with Article 38(1) and $\mathrm{P}(1)$ of the Fundamental Law. The state, as the exclusive owner, can only manage groundwater (including the possibility of water usage) in a way that takes into account the needs of future generations and natural resources as values in themselves. ${ }^{27}$

The key point within the argumentation and interpretation is the so-called non-derogation principle, ${ }^{28}$ meaning that the level of protection for environment previously achieved cannot be lowered and derogated from (or even endangered). The Constitutional Court pointed out that "the principle of non-derogation as the

Id. Reasoning [48].

See in Hungarian at www.ajbh.hu/documents/10180/2854783/AB_valasz_k\%C3\%BAtf \%C3\%BAr\%C3\%A1s_2018.pdf/e7ba687f-6bf9-fe45-6b99-eca04ac118b6.

Decision No. 13/2018. (IX. 4.) AB, Reasoning [49].

Id. Reasoning [50].

Id. Reasoning [54].

Id. Reasoning [16], [17] and [18]. 
State's additional obligation related to the environmental regulation was directly deductible from Article P."29

The Constitutional Court recalled its earlier practice regarding the nonderogation principle. ${ }^{30}$ It follows from the subject matter and the dogmatic character of the right to the environment that the level of protection guaranteed by law shall not be derogated from by the state, unless this is unavoidable for the enforcement of other constitutional rights or values (subject to the necessity and proportionate nature of the amending legislation). According to the case-law of the Constitutional Court, the non-derogation principle derives directly from the Fundamental Law and it is closely related to Articles $\mathrm{P}(1)$ and $\mathrm{XXI}(1){ }^{31}$ Furthermore, the Constitutional Court also emphasized that in all cases when the legislation on environmental protection is amended, the legislator shall also take into account the principles of precaution and prevention, since their violation could trigger irreversible consequences in the ecosystem. ${ }^{32}$ The non-derogation principle, however, does not exclude modification causing negative effects in itself, but

"legislator should verify that the regulation is not a step-back and this way it does not cause any irreversible damage as the case may be, and it does not provide any ground in principle for causing such damage." 33

The Constitutional Court recalled the obligations of present generation towards future generations to preserve the quality of the natural environment. As the decision emphasizes

"the present generation is bound to preserve the opportunity of choice, to preserve the opportunity of quality and to preserve the opportunity of access. Securing the opportunity of choice is based on the consideration that is how the life conditions of future generations can be secured best."34

However, legislation which fails to encourage the prudent management of natural resources also violates the requirement of Article $\mathrm{P}(1)$ of the Fundamental Law. In the present case, the significant risk of deterioration posed by unauthorized wells is also a threat for the living conditions of present generations. ${ }^{35}$ By explicitly mentioning in Article $\mathrm{P}(1)$ the obligation to preserve the common

29 See Decision No. 28/2017. (X. 25.) AB, Reasoning [28].

30 See Decision No. 28/1994. (V. 20.) AB, ABH 1994 133, 140; Decision No. 3068/2013. (III. 14.) AB, Reasoning [53]; Decision No. 3223/2017. (IX. 25.) AB, Reasoning [28].

31 As the Constitutional Court underlined, "Article $\mathrm{P}(1)$ can be seen as both the guarantee of the fundamental human right enshrined in Article XXI (1), and a sui generis obligation providing for the protection of the nation's common heritage, to be generally enforced beyond the scope of Article XXI(1).” Decision No. 13/2018. (IX. 4.) AB, Reasoning [14].

32 Id. Reasoning [103].

33 Id. Reasoning [20].

34 Id.

35 Through Article XX (right to physical and mental health) and XXI (right to a healthy environment). 
heritage of the nation for future generations, the Fundamental Law also foresees that legislation should not only take into account the individual and common needs of the present generation. It is also necessary that the interests of the living conditions of future generations as well as the precautionary and prevention principles be taken into account by analyzing the potential effects of the decision based on the current state of science and knowledge (which is the starting point for exercising precaution). Therefore, allowing for unauthorized water abstraction without permission and notification in itself amounts to a violation of the non-derogation principle irrespective of the fact whether it's the exact details had been regulated later or not. Prescribing mandatory permission can play a role in limiting the water use of individual water users, as such, it is also a tool for the state to enforce its responsibility for preserving the common heritage of the nation for the future generations. According the interpretation given by the Constitutional Court,

"The State as an exclusive owner may only manage groundwaters (including providing for the possibility of using the waters) by considering not only the common needs of the present generations, but the needs of future generations as well, while also regarding natural resources as regulatory subjects that represent intrinsic value worth protecting." 36

The Constitutional Court also recalled that according to the generally accepted precautionary principle under environmental law, the state shall ensure that the deterioration of the environment does not occur as a result of a certain measure. ${ }^{37}$ It also underlined that the prevention principle shall be preferred over ex post follow-up sanctions and a subsequent application of the polluter pays principle. ${ }^{38}$ The Constitutional Court emphasized that repealing the permission and notification procedure violates both Article XXI(1) (right to a healthy environment) and Article XX(1) (right to physical and mental health) of the Fundamental Law, ${ }^{39}$ in respect of both the present and the future generations.

The consistent practice of the Constitutional Court shows that the nonderogation principle shall be the threshold and main requirement for reviewing environmental legislation, and the present amending draft act is not in conformity with that well-elaborated principle with the status of constitutional protection. Thus, the Constitutional Court declared that "due to the declaration

36 Decision No. 13/2018. (IX. 4.) AB, Reasoning [54].

37 As the Constitutional Court stated: "The precautionary principle is also known in and applied by the international law (in particular the Convention on Biological Diversity, the United Nations Framework Convention on Climate Change promulgated with the Act LXXXII of 1995, the Cartagena Protocol on Biosafety to the Convention on Biological Diversity) and the international case-law [ECtHR, Tatar v. Romania (67021/01), 27 January 2009]. As underlined by the ECtHR in the decision referred to above, in case of a danger of damage, States shall assess the risks and they shall take the steps necessary for protection and prevention. The obligation of assessing risks shall be continuously applicable throughout licensing and exercising the activity." Id. Reasoning [83].

38 Id. Reasoning [63].

39 Id. Reasoning [72]. 
of its conflict with the Fundamental Law, the Act shall not be promulgated in accordance with Section 40(1) of the CC Act." 40

\section{Concurring and Dissenting Opinions}

Justices Czine, Schanda and Stumpf attached concurring opinions, while Justices Dienes-Oehm, Juhász, Pokol, Szívós and Varga attached dissenting opinions to the decision.

\subsection{Concurring Opinions}

The concurring opinions differ from the majority decision by highlighting the more serious constitutional challenges based on Section 4 of the draft act rather than Section 1 (upon which the majority decision was adopted), while agreeing with the aim of preserving the quality and quantity of groundwater. ${ }^{41}$ As it mentioned above, Section 4 added the scope of unauthorized activities and additional procedures and details which were to be regulated by the Government in the future (in the form of a government decree under the Act).

These opinions confirm the possibility of modifying the procedure, while there is no clear prohibition requirement under the derogation principle, however

"The prohibition of step-back should be assessed in light of the entire regulatory context, rather than by itself. Therefore, the fact that the legislative amendment under review is in conflict with the principle of nonderogation does not mean an absolute prohibition for the State to reform the system of guarantees governing the protection of groundwaters, however, the State should make it clear that the changes do not lead to the reduction of the level of protection and they properly ensure the protection of state property." 42

The standard shall be the requirement of precautionary principle (rather than the non-derogation principle itself), and the legislative amendment does not provide any guarantee for the introduction of more effective ex-post supervision by authorities to secure the State's presence in the regulatory area. ${ }^{43}$ The amendment of the draft legislation

40 Id. Reasoning [75]. Section 40(1) of the Act on the Constitutional Court reads as follows: "The Act may not be promulgated if the Constitutional Court declares that the provision or provisions of an Act examined within the framework of proceedings specified in Section 23."

41 Justice Czine pointed out the non-conformity and unconstitutionality of Section 4 of the amending legislation, which had not been reviewed by the Constitutional Court, since the violation had been declared already upon Section 1 of the Act. Id. Concurring opinion by Ágnes Czine, [96] and [97].

42 Id. Concurring opinion by Balázs Schanda, [99]. See also the same interpretation by Justice Stumpf. Id. Concurring opinion by István Stumpf, [105].

43 Id. 
"opens up the possibility for regulating the issue per government decree, reducing the former level of protection of water stocks, which is against the requirement of precaution and contrary to the State's obligation to carefully protect the nation's natural heritage and preserve it for future generations." ${ }^{4}$

The concurring opinions center on the point that unauthorized (Section 1 of the amending legislation) water abstraction is not unconstitutional per se, however a pro futuro, posterior government decree (upon Section 4 of the amending legislation) introduces uncertainty to groundwater abstraction without clear normative guarantees of precaution which would preserve the quality and quantity of water stocks.

\subsection{Dissenting Opinions}

All dissenting opinions highlight that the Constitutional Court delivered its decision without knowing how the government decree which was to specify the additional details and rules would have been framed, rendering its decision on non-conformity in lack of this information. The judges authoring the dissenting opinions, therefore, held that the majority decision cannot declare that the nonderogation principle had been unconstitutionally violated. According to the argumentation of the dissenting opinions, such 'prematurity' ${ }^{45}$ and the lack of future regulation cannot be constitutionally challenged ${ }^{46}$ on the basis of the simple hiatus of the government decree itself. Since the details of the implementing provisions have inevitably not been passed in a decree, their conformity with the Fundamental Law cannot be established in an ex ante fashion. One dissenting opinion emphasized,

"Without being aware of the rules of the future government decree, we cannot reach a well-founded conclusion on whether the challenged provisions of the law were in conflict with the Fundamental Law. Therefore [...] it is not possible to state with constitutional certainty that the challenged regulations reduce the level of protection achieved." 47

Another opinion expressly mentioning concerns regarding the majority decision points out that

Id. [106].

45 Justice Dienes-Oehm attached dissenting opinion to the decision by adding that "the constitutional review may only take place after the adoption of the implementing regulation, thus the majority decision is 'premature' to declare the conflict with the Fundamental Law." Id. Dissenting opinion by Egon Dienes-Oehm, [110]-[111]. Justice Juhász pointed out in his dissenting opinion that "implementing the Acts is the duty of the Government [...] even before the Government had an opportunity to adopt this decree, the majority decision deprived it of the chance to implement the Act." Id. Dissenting opinion by Imre Juhász, [115].

46 Justice Pokol attached his opinion by highlighting that "the concerns raised in the petition with regard to the Government decree-level regulation to be issued in the future could have been remedied by placing a constitutional warning in the reasoning of the decision.", Id. Dissenting opinion by Béla Pokol, [122]. 
"the probability of the injury should obviously be subject to an assessment, since we cannot set a general rule about the degree of probability that refutes the presumption; this needs to be determined individually in each case." ${ }^{8}$

Thus, all five dissenting opinions stated that the Constitutional Court cannot make such a decision without being aware of the government decree on the specifications and detailed rules of water abstractions.

\section{Assessment}

Upon the decision of the Constitutional Court, the Minister of Interior withdrew the amending legislation, with the effective rules remaining in force since then. The decision reaffirmed the consistent and already elaborated non-derogation principle. It is worth recalling the words of the Deputy Commissioner, who stated that

"instead of imposing sanctions, the authorities should develop and implement procedures imposing bearable administrative and financial burden on ordinary citizens, encouraging their compliance with the law." 49

The Constitutional Court underlined in its decision that the principles of precaution and prevention should be taken into account since the failure to protect the nature and the environment may induce irreversible processes. ${ }^{50}$ Groundwater reserves are finite in terms of their quantity and quality, and they are renewable only to a limited extent. ${ }^{51}$ Therefore, it has to be stated that the main observation and finding of the Constitutional Court on environmental issues remained unchanged, thus, the principle of non-derogation remains the test for reviewing the constitutional protection of environment-related rights and state aims. It is worth mentioning that Hungary is among those states, whose "constitutions also identify environmental protection as a matter of national policy, and some recognize specific rights concerning water, sustainability, nature, public trust and climate change."52 Thus, while the Constitutional Court refrained from citing relevant EU law sources, it applied the overarching principles of precaution and prevention, which are still within the practice of the

48 Id. Dissenting opinion by András Zs. Varga, [138].

49 See at www.ajbh.hu/web/ajbh-en/-/the-ombudsman-for-future-generations-on-the-deadlinesfor-approval-of-wells-drilled-without-a-permit.

50 Decision No. 13/2018. (IX. 4.) AB, Reasoning [20].

51 Id. Reasoning [36].

52 See James May \& Erin Daly (eds.), Global Judicial Handbook on Environmental Constitutionalism. Third Edition, UNEP, 2019, p. 104. About two-thirds (126) of the constitutions in force worldwide address natural resources in some fashion, including water (63), land (62), fauna (59), minerals and mining (45), flora (42), biodiversity or ecosystem services (35), soil/sub-soil (34), air (28), nature (27), energy (22), and other (17). 
Constitutional Court and continue provide the threshold for the review of fundamental environmental rights and aims under the new Fundamental Law. ${ }^{53}$

I understand this decision to be a clear sign of a continued precautionary and preventive approach to environmental regulation, as originally framed under the non-derogation principle back in the 1994 decision of the Constitutional Court. Since then, the Constitution and the relevant laws on the Hungarian Constitutional Court have significantly changed, but the non-derogation principle remained a constitutional value and interpretative aid based on Articles $\mathrm{P}$ and XXI of the Fundamental Law. The current regulation neither prohibits, nor allows unrestricted water abstraction, hence the permission system can be regarded as a guarantee for the environmentally sound and sustainable usage of groundwater which is a clear value and procedural check to be continuously protected and maintained. The Constitutional Court reconfirmed this value under the interpretation of Articles XX and XXI as well as Article P of the Fundamental Law. It clearly shows the longevity of the non-derogation principle as the prerequisite of future environmental legislation. In my view, the decision cannot be considered a pro futuro ban on, and aggravation of water abstraction, since for the time being, the permission and notification procedure allows for groundwater usage after evaluation and review by the authority. This professional (hydrological reasonableness and justification), legal as well as institutional control within the process shall prevail in all environmental matters. 